Das Fluor

und seine Verbindungen

von

\title{
Henri Moissan.
}

Professor an der École Supérieure de Pharmacie in Paris,

Mitglied der Académie des Sciences etc. etc.

Autorisierte deutsche Ausgabe

übersetzt von

Dr. Theodor Zettel.

Mit 21 in den Text gedruckten Abbildungen.

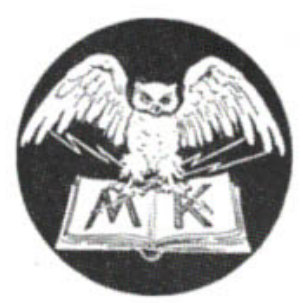

BERLIN W.

Verlag von M. Krayn.

1900. 
